\title{
Bacterial translocation in an experimental intestinal obstruction model. C-reactive protein reliability? ${ }^{1}$
}

\author{
Translocação bacteriana no modelo experimental de obstrução intestinal. A proteína C-reativa \\ é confiável?
}

\author{
Saleh Ibrahim El-Awady', Mohammed El-NagarI, Medhat El-Dakar ${ }^{I I I}$, Mohammed Ragab ${ }^{\text {IV }}$, Ghada EInady \\ ${ }^{I}$ MD. Assistant Professor, Department of Surgery, Mansoura Faculty of Medicine, Mansoura University, Egypt. \\ ${ }^{\text {II }}$ MD. Assistant Professor, Department of Microbiology, Mansoura Faculty of Medicine, Mansoura University, Egypt. \\ ${ }^{\text {III }}$ MD. Lecturer, Department of Microbiology, Mansoura Faculty of Medicine, Mansoura University, Egypt. \\ ${ }^{\text {IV }}$ MD. Lecturer, Department of Histology, Mansoura Faculty of Medicine, Mansoura University, Egypt. \\ ${ }^{v}$ MD. Lecturer, Department of Microbiology, Mansoura Faculty of Medicine, Mansoura University, Egypt.
}

\begin{abstract}
Background: Bacterial translocation occurs in preseptic conditions such as intestinal obstruction through unclear mechanism. The C-reactive protein is an acute phase reactant and a marker of ischemia. Methods: 45 albino male rats were divided into 3 groups each 15 rats. GI control, GII simple intestinal-obstruction and GIII strangulated obstruction. Outcome measures were: (1) Bacteriologic count and typing for intestinal contents, intestinal wall, liver, mesenteric lymph nodes and blood (cardiac and portal) (2) Histopathologic: mucosal injury score, inflammatory cell infiltrate in the wall, MLN, liver, (3) Biochemical: serum CRP, IL-10, mucosal stress pattern (glutathione peroxidase-malonyldialdhyde tissue levels). Results: (1) Intestinal obstruction associates with BT precursors (Bact-overgrowth, mucosal-acidosis, immuno-incomptence), (2) Bacterial translocation (frequency and density) was found higher in strangulated I.O, that was mainly enteric (aerobic and anaerobic) and mostly E.coli, (3) The pathogen commonality supports the gut origin hypothesis but the systemic inflammatory response goes with the cytokine generating one. (4) The CRP median values for GI, II, III were $0.5,6.9,8.5 \mathrm{mg} / \mathrm{L}$, for BT +ve $8 \mathrm{mg} / \mathrm{L}$ and $0.75 \mathrm{mg} / \mathrm{L}$ for BT -ve rats. Conclusion: Bacterial translocation occurs bi-directional (systemic-portal) in intestinal obstruction and the resultant inflammatory response pathogenesis is mostly 3 hit model. The CRP is a non selective marker of suspected I.O cases. However, it is a reliable marker of BT, BT density and vascular compromise during I.O.
\end{abstract}

Key words: Intestinal Obstruction. Ischemia. Bacterial Translocation. Rats.

\section{RESUMO}

Objetivo: Translocação bacteriana ocorre em condições pré-sépticas como na obstrução intestinal por mecanismo não esclarecido. A proteína C-reativa é um marcador de ischemia em fase aguda. A proposição é investigar os possíveis efeitos da obstrução intestinal no equilíbrio ecológico microbiano. Métodos: 45 ratos machos albinos foram distribuídos em três grupos de 15 ratos. GI controle, GII obstrução intestinal simples e GIII obstrução estrangulada. As medidas adotadas foram: (1) Contagem bacteriológica do conteúdo intestinal, parede intestinal, fígado, linfonodos mesentéricos e sangue (coração e portal) (2) Avaliação histopatológica da lesão da mucosa, infiltrado celular inflamatório da parede, linfonodos mesentéricos, fígado, (3) Avaliação bioquímica. Resultados: (1) Obstrução intestinal está associada a precursora translocação bacteriana (crescimento bacteriano, acidose da mucosa, imuno-incompetência), (2) Translocação bacteriana (freqüência e densidade) foi maior na obstrução intestinal estrangulada, principalmente entérica (aeróbios e anaeróbios), sobretudo E.coli, (3) A ocorrência comum é de origem intestinal. Conclusão: A translocação bacteriana na obstrução intestinal é bi-direcional (sistêmica e portal) A proteina C-reativa não é um marcador seletivo na suspeita de obstrução intestinal. Contudo é marcador confiável da translocação bacteriana, na densidade e comprometimento durante a obstrução intestinal.

Descritores: Obstrução intestinal. Ischemia. Translocação Bacteriana. Ratos. 


\section{Introduction}

Intestinal obstruction (IO) is a common lethal abdominal emergency resulting in high mortality, mostly due to multiorgan dysfunction syndrome (MODS) ${ }^{1}$, significantly bacterial translocation (BT) together with septic peritonitis are the major contributors of MODS in $\mathrm{IO}^{2}$.

Early studies focused on BT as a unifying mechanism to explain MODS but recently other specific mechanisms are operational (immuno inflammatory) ${ }^{3}$.

Bacterial translocation is precipitated by bacterial overgrowth disturbing the normal ecologic balance ${ }^{4,5}$, host immunedysfunction inciting pro and anti-inflammatory cytokines balance ${ }^{6}$, and mucosal barrier dysfunction, favoring oxidants release $^{7}$

Apart from computerized tomography, no reliable diagnostic test for intestinal strangulation is currently available, that is costy and not reproducible ${ }^{8}$.

Lastly the C-reactive protein (CRP) which is an inflammatory marker, is considered a marker of ischemia and neovascularization ${ }^{9,10}$, hence validated in this study for detection of IO, IO subtypes and BT.

\section{Aim of work}

Is to study the possible effects of I.O on the microbiologic ecologic balance, chemical and immunologic barriers that bring protection against B.T., to demonstrate BT during I.O (pathogen typing, routes and commonality) in addition to the BT local and systemic inflammatory response as well as CRP reliability in studying BT and I.O.

\section{Methods}

This study was conducted in Mansoura Faculty of Medicine, Histology experimental laboratory unit from June 2003 to June 2006 that entails 45 albino male rats divided into 3 group each 15 rats. Group I as a control, Group II represents simple I.O group (simple ileal ligation $5 \mathrm{~cm}$ proximal to caecum) and group III comprises strangulated I.O group (symmetrical ligation of a 5 $\mathrm{cm}$ ileal loop with its mesentry, $5 \mathrm{~cm}$ proximal to caecum).

\section{Surgical maneuver}

Anaesthesia with intramuscular ketamine, $5 \mathrm{mg} / \mathrm{kg}$ body weight for GII and GIII, followed by midline laparotomy after sterilization to perform the intented I.O type and layered abdominal closure using vicryloo.

Subsequent to recovery all groups were held in a semi-acclimitized room at $23^{\circ} \mathrm{C}( \pm 2)$, both laboratory chow and tap water were allowed for 28 hours till relaparotomy.

In the $2^{\text {nd }}$ laparotomy (same anaesthetic procedure for the three groups). Under complete sterile conditions a thoracoabdominal generous midline incision was performed and firstly direct cardiac blood sampling, second portal venous blood sampling, thirdly left hepatic lobe resection, fourthly multiple mesenteric lymph nodes excision, and fifthly ileal segment proximal to ligature i.e obstruction level in GII, strangulated ileal loop in GIII and ileal segment in GI resection together with their luminal contents. Lastly animals were sacrificed via cervical dislocation.

\section{Laboratory studies:}

\section{Biochemical study}

(1) Ileal loop oxidant and antioxidant activity, were studied (2) Serum CRP and IL-10 levels were assayed.

(1)a. Oxidant (Malonyldialdhyde (MDA)): The tissue samples were homogenized with $0.1 \mathrm{ml} / \mathrm{L}$ phosphate buffer saline centrifuged at $2000 \mathrm{rpm}$ and MDA was detected at OD (optical density) $534 \mathrm{~nm}^{11}$. (1)b. Antioxidant (Glutathione peroxidase) was measured using NAD PH oxidation principle and measured at OD 340 $\mathrm{nm}^{12}$.

(2)a. CRP semiquantitative assay was performed using latex agglutination test with normal cutoff $\leq 0.5 \mathrm{mg} / \mathrm{L}$ (Human, Germany). (2)b. IL-10 (inerleukin-10) serum level was measured using commercially available ELISA kits (Diaclone, France).

\section{Histopathologic study}

(1) Ileal segments were examined to score the mucosal injury ${ }^{13}$. (2) Ileal segment, MLN, liver samples were examined for inflammatory cell infiltrate grading (GI: one $/ \mathrm{mm}^{3}$, GII $2-4 / \mathrm{mm}^{3}$, GIII: $\left.\geq 5 / \mathrm{mm}^{3}\right)^{14}$

\section{Bacteriologic study}

(1) Luminal contents, (2) Intestinal wall, MLN and liver tissues, (3) Cardiac and portal blood. Samples were collected for detection of their colony forming unit (CFU) index and bacterial species by gram stain, characteristic biochemical reaction and antibiotics susceptibility.

(1) Luminal contents were homogenized in sterile isotonic saline, plated on McConkay and Columbia blood agar (aerobic and anaerobic) (Oxid-Germany), (2) For the intestinal wall, liver, MLN. The tissues were ground in phosphate buffered saline, then plated as the contents and incubated in the Gas Park system for anaerobic culture, (3) For the blood samples they are centrifuged at $3000 \mathrm{rpm}$ for $30 \mathrm{~min}$ and the sediments were plated as the tissues.

\section{Statistical analysis}

- The CRP values are expressed as median, other variables as mean $\pm \mathrm{SD}$ and the CFU are logarithmically converted.

- For comparison the Chi-square test, Mann Whitney U test and one way ANOVA test are used when applicable.

- The pearson correlation test was used to detect CRP levels correlation with CFU density within different tissues, meanwhile the logistic regression was used to detect the significant predictors.

\section{Results}

Intestinal obstruction mainly the strangulated type is significantly associated with bacterial overgrowth, oxidative stress pattern (disproportionate MDA and GPx increase) and deranged IL-10 response (significant decrement of IL-10 levels) (Table 1). 
TABLE 1 - Bacterial translocation predisposing factors among the studied groups

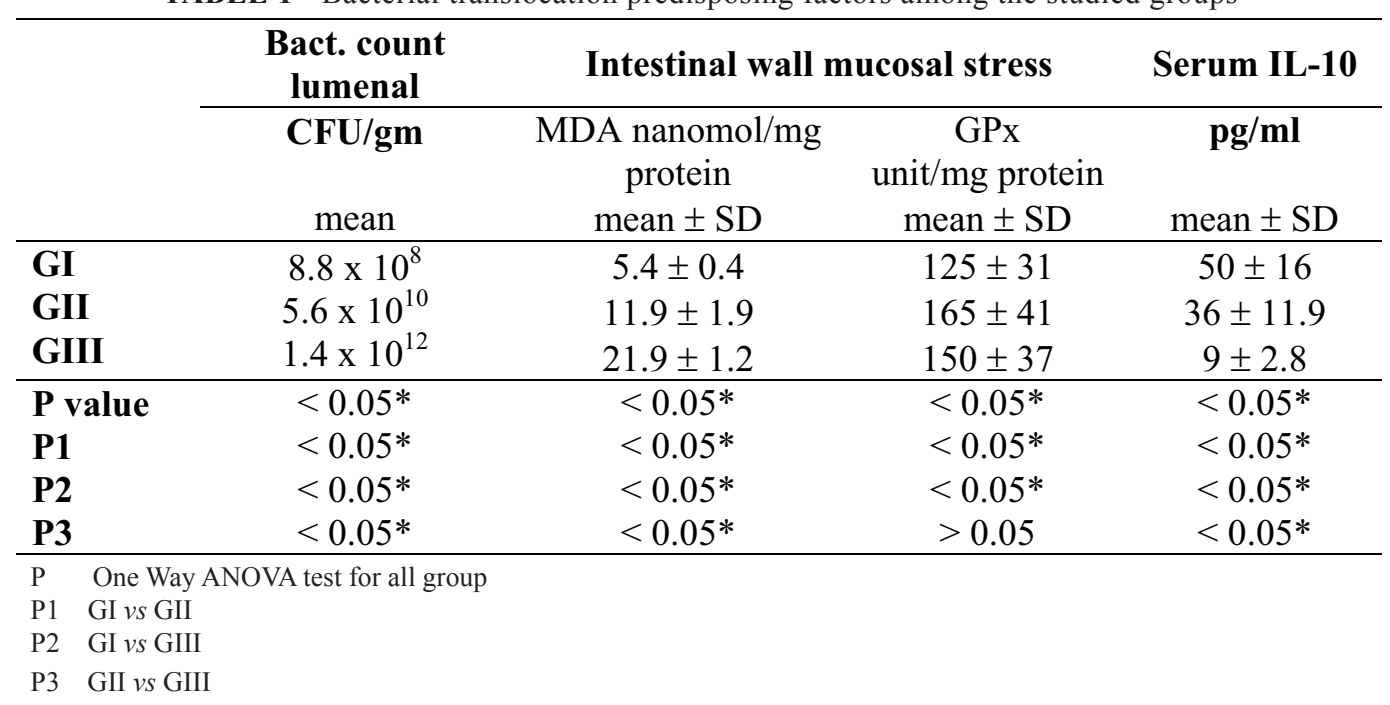

The frequency and density of BT were higher in GIII than in GII but not detected in GI, their distribution was centrifugal (lumen - wall - MLN - liver - blood) (Table 2).

TABLE 2 - Frequency and density of bacterial translocation in the tissues among the studied groups

\begin{tabular}{|c|c|c|c|c|c|c|c|c|c|c|c|c|c|c|c|}
\hline & \multicolumn{3}{|c|}{ Wall } & \multicolumn{3}{|c|}{ MLN } & \multicolumn{3}{|c|}{ Liver } & \multicolumn{3}{|c|}{ Systemic } & \multicolumn{3}{|c|}{ Portal } \\
\hline & & & Mean & & & Mean & & & Mean & & & Mean & & & Mean \\
\hline & No & $\%$ & $10^{7} \log$ & No & $\%$ & $10^{7} \log$ & No & $\%$ & $10^{6} \log$ & No & $\%$ & $10^{3} \log$ & No & $\%$ & $10^{3} \log$ \\
\hline$\overline{\text { GI }}$ & - & - & - & - & - & - & - & - & - & - & - & - & - & - & - \\
\hline GII & 12 & 80 & 7.77 & 9 & 60 & 7.15 & 7 & 46.6 & 6.78 & 3 & 20 & 3.81 & - & - & - \\
\hline GIII & 15 & 100 & 7.9 & 12 & 80 & 7.85 & 10 & 66.6 & 6.83 & 6 & 40 & 3.78 & 3 & 20 & 3.93 \\
\hline
\end{tabular}

The bacterial translocation was commonly polymicrobial (49\% in GII - 60\% in GIII), mostly enteric with substantial anaerobic ratio and E.coli predominance (42.2\% in GII and $45.5 \%$ in GIII) (Table 3).

TABLE 3 - Frequency and types of isolated organisms

\begin{tabular}{|c|c|c|c|c|c|c|c|c|c|c|c|c|c|c|c|c|c|c|}
\hline & \multicolumn{9}{|c|}{ GII I.O } & \multicolumn{9}{|c|}{ GIII I.O } \\
\hline & \multirow{3}{*}{$\begin{array}{c}\begin{array}{c}\text { Isolat } \\
\text { No }\end{array} \\
64\end{array}$} & \multicolumn{17}{|c|}{ Isolates } \\
\hline & & \multicolumn{6}{|c|}{ Enteric } & \multicolumn{2}{|c|}{ Non } & \multirow{2}{*}{$\begin{array}{c}\text { No } \\
84\end{array}$} & \multicolumn{6}{|c|}{ Enteric } & \multicolumn{2}{|c|}{ Non } \\
\hline & & 1 & 2 & 3 & 4 & 5 & 6 & 7 & 8 & & 1 & 2 & 3 & 4 & 5 & 6 & 7 & 8 \\
\hline Luminal & 20 & 9 & 1 & 2 & 3 & 2 & 3 & 2 & 3 & 21 & 10 & 3 & 3 & 3 & 3 & 4 & 4 & 3 \\
\hline Wall & 16 & 7 & 1 & 1 & 2 & 2 & 3 & 2 & 3 & 19 & 9 & - & 2 & 2 & 2 & 2 & 2 & 1 \\
\hline MLN & 13 & 5 & - & 1 & 1 & - & 1 & 1 & 1 & 17 & 8 & - & 2 & 1 & 2 & 1 & 3 & 1 \\
\hline Liver & 11 & 4 & - & - & 1 & - & - & - & 1 & 15 & 6 & 1 & 1 & 1 & - & - & 1 & 1 \\
\hline $\mathrm{BL}$ & 4 & 2 & - & 1 & 1 & - & - & 1 & - & 8 & 3 & 1 & 1 & 1 & - & - & 2 & - \\
\hline Portal & 0 & - & - & - & - & - & - & - & - & 4 & 2 & - & 1 & - & - & - & 1 & - \\
\hline $\begin{array}{l}\text { 1 E.coli } 2 \mathrm{~K} \\
* \text { E.coli } \\
* \text { Polymi }\end{array}$ & $\begin{array}{l}\text { Clebsila ox } \\
\text { n GII } 42.2^{\circ} \\
\text { cro in GII }\end{array}$ & & & & & & & & 8 & dium & cteroids & & agul & e sta & & eudo & onas & \\
\hline
\end{tabular}


The pathogen commonality in the simple I.O was highest lumen to wall, lowest lumen to blood (Figure 1A) and in the strangulated group was highest lumen to wall, blood, MLN and modest lumen to blood (Figure 1B).

(A) Simple I.O

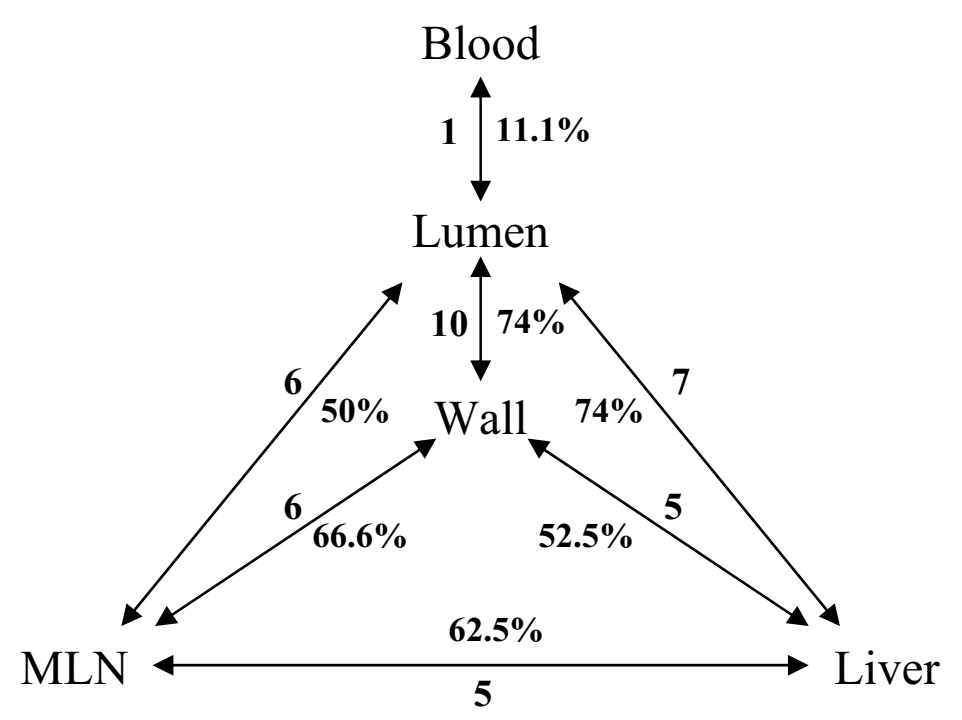

(B) Strangulated I.O

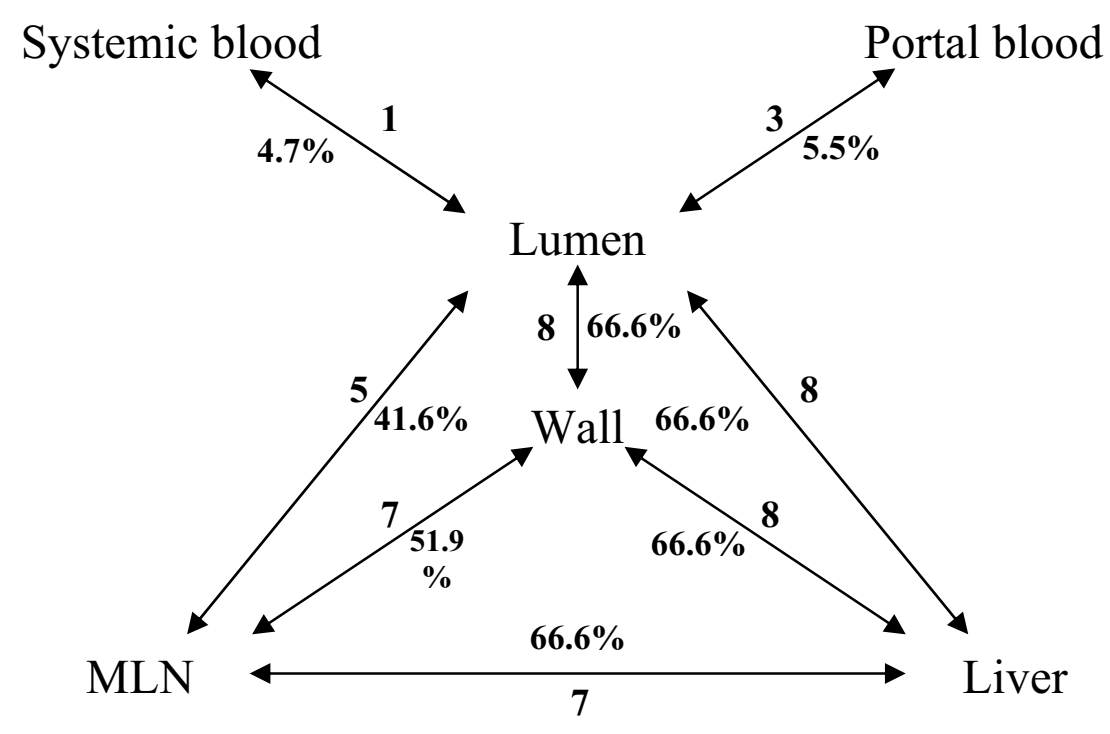

FIGURE 1 - Disease commonality 
The mucosal injury score and inflammatory cell infiltrate were significantly higher in GIII (Figure 2).
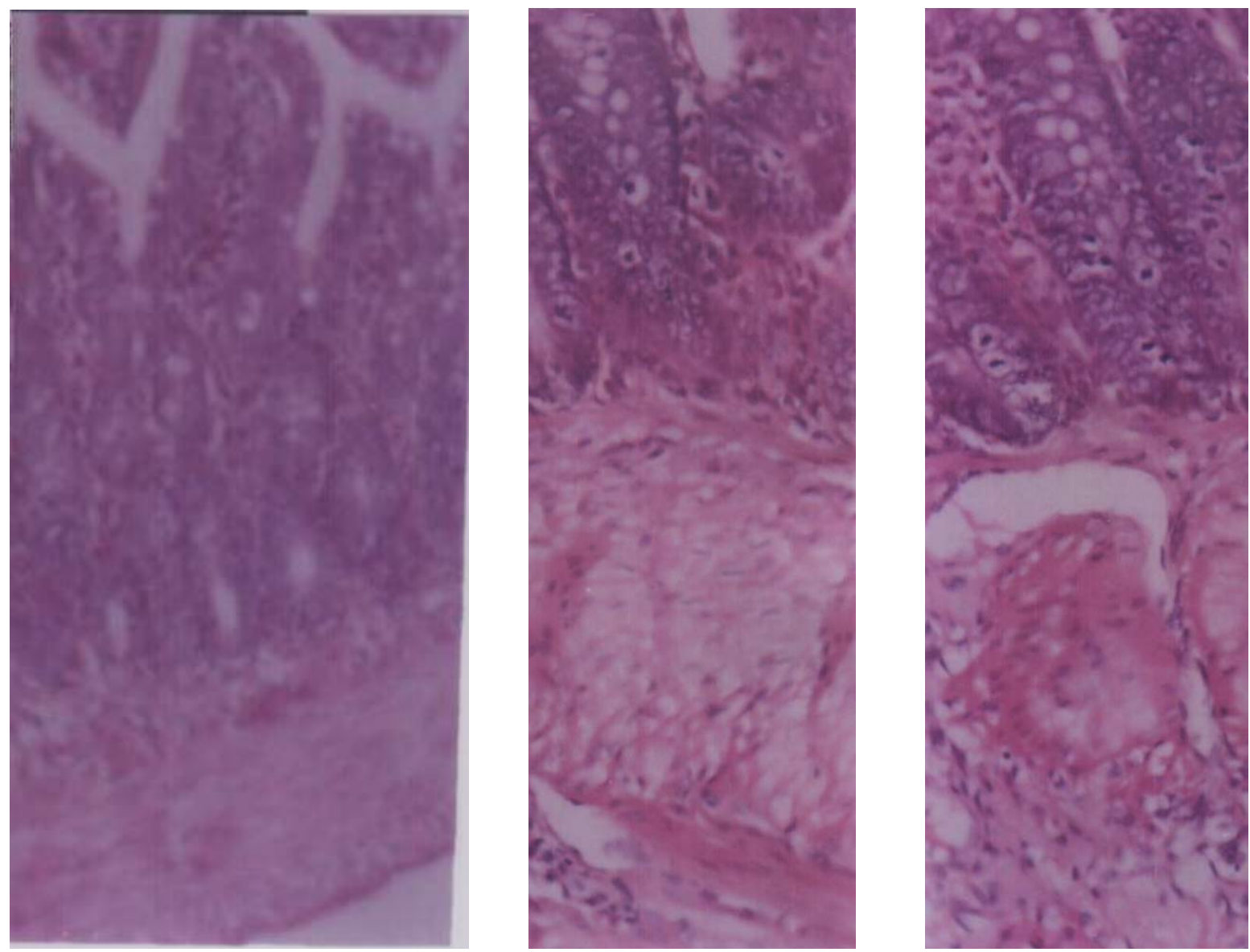

FIGURE 2 - Photomicrographs of the local inflammatory response in the studied groups (100X)

Also the local and remote inflammatory response (liver + MLN inflammatory cell infiltrates) was higher in GIII (Table 4).

TABLE 4 - The local and remote inflammatory response

\begin{tabular}{|c|c|c|c|c|c|c|c|c|c|}
\hline & \multicolumn{4}{|c|}{ Wall } & \multicolumn{3}{|c|}{ Liver } & \multicolumn{2}{|c|}{ MLN } \\
\hline & \multirow{2}{*}{$\begin{array}{l}\text { Score of } \\
\text { mucosal } \\
\text { injury }\end{array}$} & \multicolumn{3}{|c|}{ Inf cell infilt } & \multicolumn{3}{|c|}{ Inf cell infilt } & \multicolumn{2}{|c|}{ Hyperplasia } \\
\hline & & 1 & 2 & 3 & 1 & 2 & 3 & + & - \\
\hline GI & 0.9 & 1 & 11 & 3 & 12 & 2 & 1 & 1 & 14 \\
\hline GII & 2.4 & 1 & 5 & 9 & 1 & 4 & 10 & 9 & 6 \\
\hline GIII & 4.3 & 0 & 1 & 14 & 0 & 0 & 15 & 15 & 0 \\
\hline P value & $<0.05^{*}$ & \multicolumn{3}{|c|}{$<0.05^{*}$} & \multicolumn{3}{|c|}{$<0.05^{*}$} & \multicolumn{2}{|c|}{$>0.05$} \\
\hline
\end{tabular}

One Way ANOVA test. 
The CRP median value was significantly higher in I.O and its subtypes than control (Table 5) with higher $75 \%$ percentile ratio in GIII than in GII (Figure 3).

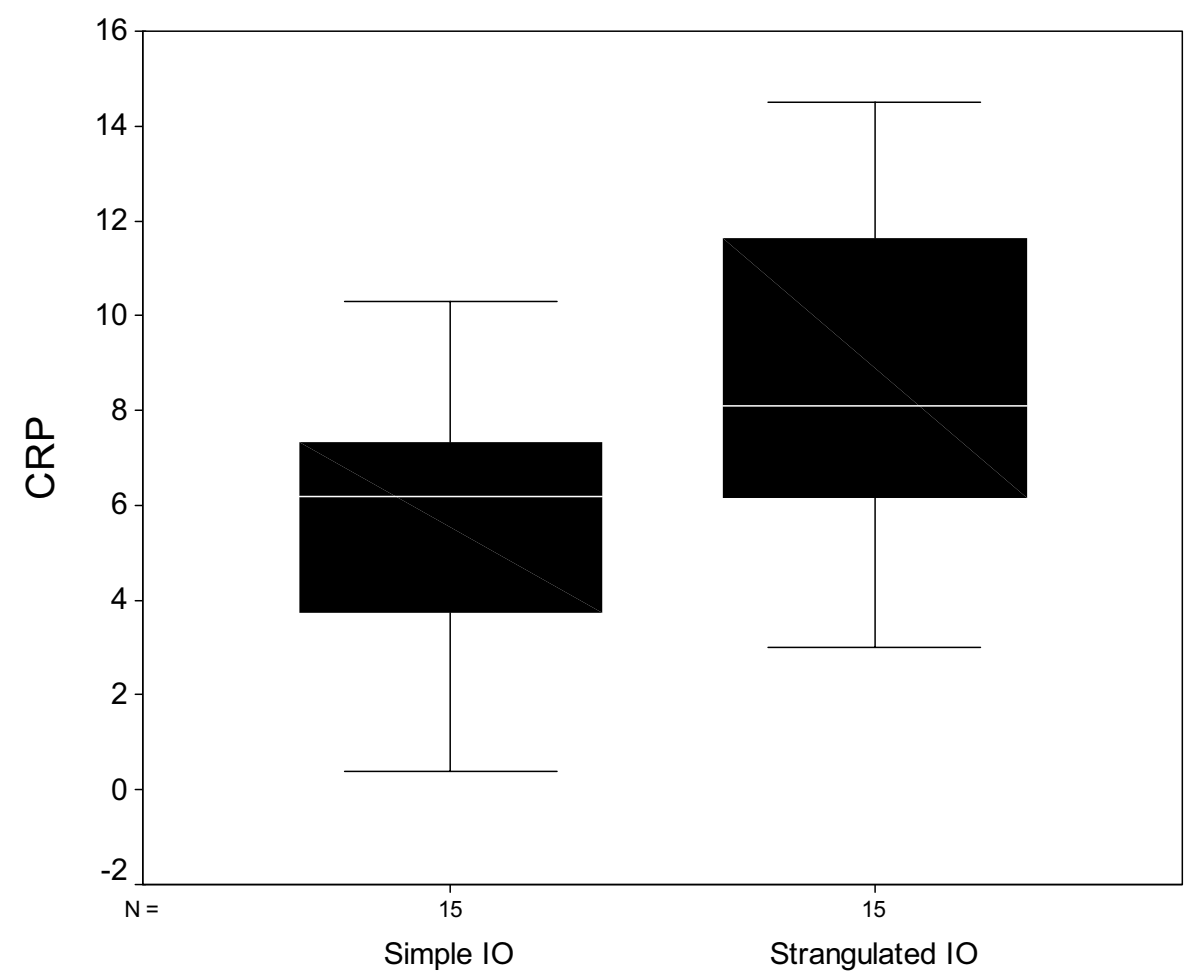

FIGURE 3 - Box blot of CRP level in simple and strangulated intestinal obstruction

But the cutoff value failed to predlict to either groups (GII and GIII in Table 5) resulting in average accurate value in I.O, subtypes detection (in simple obstruction: $56.8 \%$ - in strangulated obstruction: $46.6 \%$ ). But the logistic regression defined the CRP value as a significant predictor of strangulated I.O $[\mathrm{P}=0.026 * \mathrm{OR}=1.726,95 \% \mathrm{CI}(2.78-0.069)]$.

TABLE 5 - CRP median value and frequency of positive cases (cutoff level $0.5 \mathrm{mg} \%$ )

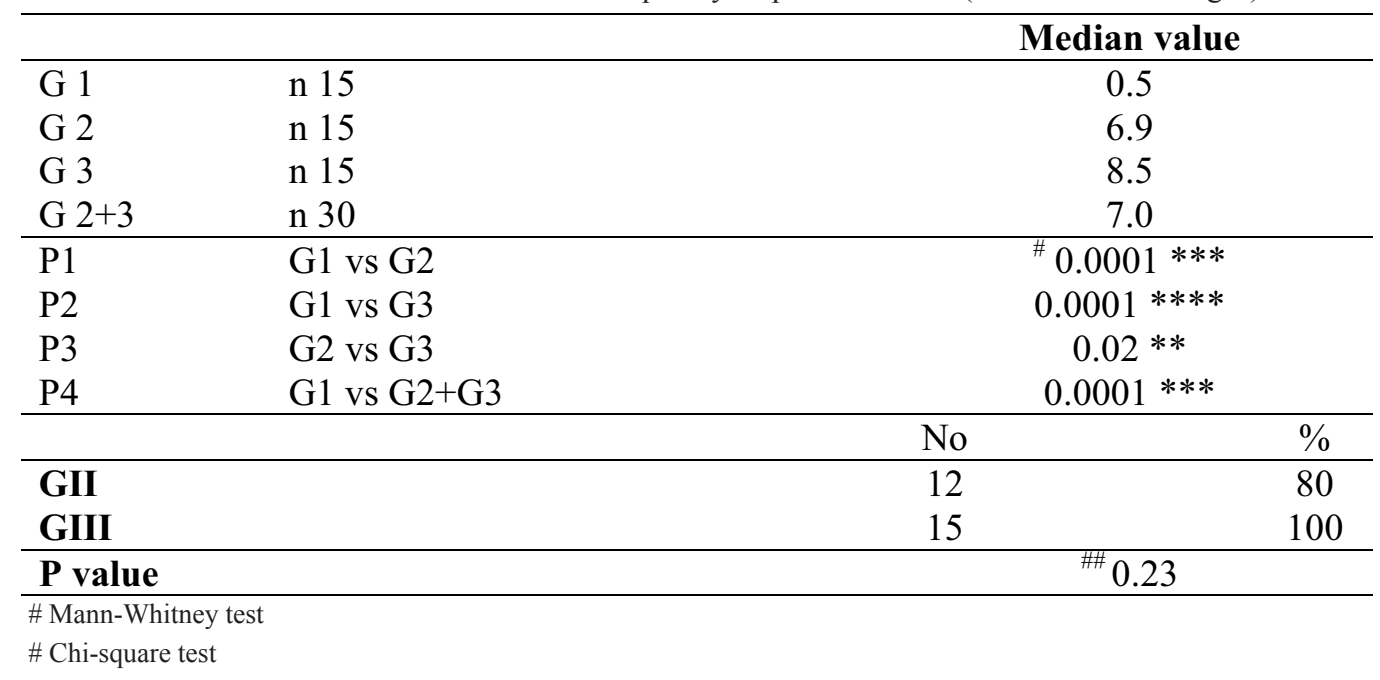


The CRP median value was significantly higher in cases of BT during I.O compared to -ve BT (Table 6) and its cutoff level significantly predicted to -ve cases resulting in good exclusion power on validation (sensitivity: $77.7 \%$, specificity: $33.3 \%$, accuracy: $(66.6 \%)$, also the logistic regression defined CRP as a significant predictor of BT during I.O $[(\mathrm{P}=0.002 * * * \mathrm{OR}=3.074$ and $95 \% \mathrm{CI}$ $(6.3-1.492)]$.

TABLE 6 - CRP relation with bacterial translocation in intestinal obstruction and frequency of positive cases

\begin{tabular}{|c|c|c|c|c|c|c|}
\hline & & & & \multicolumn{2}{|c|}{ Median CRP } & $\mathrm{P}$ value \\
\hline \multirow[t]{2}{*}{ B.T } & BT & + & n 22 & \multicolumn{2}{|c|}{$8.0^{\#}$} & $0.0001 * * *$ \\
\hline & & - & n 8 & \multicolumn{2}{|c|}{0.75} & \\
\hline \multirow[t]{2}{*}{ GII.I.O } & BT & + & n 10 & \multicolumn{2}{|c|}{7.25} & $0.001 * *$ \\
\hline & & - & n 5 & \multicolumn{2}{|c|}{0.5} & \\
\hline \multirow[t]{5}{*}{ GIII.I.O } & & BT & n 12 & \multirow{2}{*}{\multicolumn{2}{|c|}{$\begin{array}{l}12.5 \\
0.50\end{array}$}} & $0.004 * *$ \\
\hline & & - & n 3 & & & \\
\hline & & & & No & $\%$ & $\mathrm{P}$ \\
\hline & BT & + & n 22 & $17^{\# \#}$ & 77 & $<0.05^{*}$ \\
\hline & & - & n 8 & 2 & 25 & \\
\hline
\end{tabular}

\# Mann Whitney U test

\#\# Chi-Square test.

The frequency and density of BT were parallel to CRP levels in the studied tissues whether simple or strangulated obstruction but their correlations were insignificant (Figure 4).
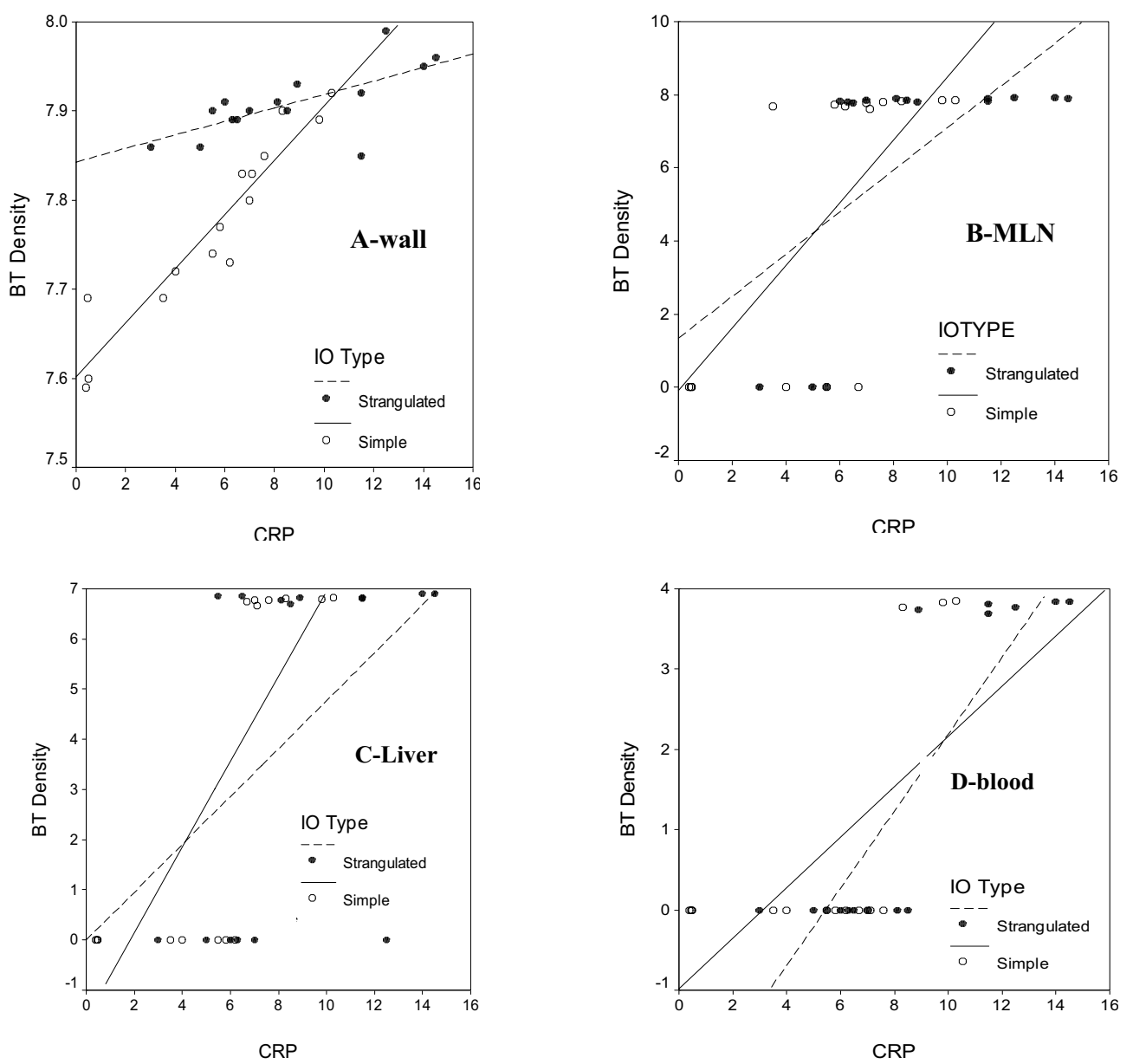

FIGURE 4 - Scatter plots showing relation between logarithmic BT density and CRP level in both simple and strangulated I.O within the wall (a), MLN (B), liver (C) and systemic blood (D) 


\section{Discussion}

Likely to the disturbed dynamic milieu of the intestinal tract during intestinal obstruction, this study defined bacterial overgrowth association with I.O in line with Akin et al. ${ }^{15}$ and Sagar et $a l .{ }^{16}$, also the oxidative stress pattern during I.O produce ATP depletion $^{17}$, cytoskeleton disruption ${ }^{18,19}$, neutrophil priming ${ }^{20}$ resulting in mechanical gut barrier dysfunction, and significantly the I.O association with impaired IL-10 response as reported by Zingarelli et al. ${ }^{21}$ and Souza et al. ${ }^{22}$ declare the immune incompetence status. Although O'Boyle ${ }^{23}$ deny those associations.

In accordance with Akcay et al. ${ }^{24}$; Antequera et al. ${ }^{25}$; Kocdor et $a l .{ }^{26}$ and Souza et al. ${ }^{22}$ BT occurred during I.O as reported here, and the centripetal decrement in the frequency and density of the pathogens supports tissue colonization is gut derived not blood derived. This study also defined BT is bidirectional during I.O specially in the ischemic variant as reported by Wells et al. ${ }^{27}$ and Mainous et al. ${ }^{28}$ and that is related to direct intestinal wall insult.

Further support for the gut origin hypothesis during I.O from this study is the enteric bacteria predominance as detected by Brooks et al. ${ }^{29}$ and MacFie et al. ${ }^{30}$. Moreover, E.coli outnumber other pathogens and this is mostly related to its facultative nature and its fimbriated surface i.e. colonizing factor thus supporting lymphatic route for BT. Furthermore, the obligate anaerobic organisms isolates detection as reported by Boedeker ${ }^{31}$; O'Boyle et al. ${ }^{32}$ and Cevikel et al. ${ }^{1}$ define the colonization resistance failure in the ischemic intestinal obstruction. So bacterial overgrowth, bacterial virulence and wall integrity (structure and function) work together.

In this study the commonality of pathogens define the gut-origin hypothesis, provides additional support for local transmural route (Phagocytes or enterocytes) in line with Deitch ${ }^{4}$; Brooks et al. ${ }^{29}$ and MacFie et al. ${ }^{30}$ who defined lymphatic route predominance in the simple I.O and venous portal predominance in the ischemic variant as found by; Moore et al. ${ }^{33}$; Lemaire et al. ${ }^{34}$; Adams et al. ${ }^{35}$ and Kocdor et al. ${ }^{26}$.

The observed local and systemic immunoinflamamtory histopathologic changes as Akcay et al. ${ }^{24}$ reported, might be related to cytokines release producing inflammatory cell influx resulting in tissue injury supporting the cytokine generating

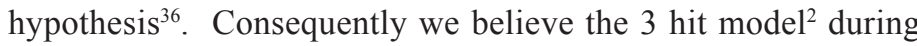
I.O $1^{\text {st }}$ (increased intestinal pressure or ischemia), $2^{\text {nd }}$ (reperfusion injury) (increased secretion and decreased absorption prostaglandin release - collaterals opening - distension) resulting gut barrier failure and $3^{\text {rd }}$ bacterial and cytokine translocation.

Despite CRP surge during I.O, its cutoff value didn't predict to any subtypes with consequent average accuracy in detection of I.O subtypes, so CRP is a non selective marker in suspected cases and confirming information from medical history and physical examination must be scrutinized to see if it support or contradicts CRP + ve cases. But significantly once I.O is diagnosed the CRP is a significant predictor of the ischemic variant as reported by Willet et $a l .{ }^{37}$.

The high CRP level was associated with B.T during I.O and its subtypes. The ability of its cutoff level to define BT with high sensitivity, specificity and accuracy was associated with a statistically significant predictor value in accordance with Cevikel et al. ${ }^{1}$ making CRP a reliable test to detect BT during I.O.
Complementary to previously found the parallel relation between CRP level and BT (frequency and density) specially the ischemic variant is mostly related to the cascades of systemic inflammatory response mediators as described by Moore ${ }^{38}$. So, CRP can be considered a predictor of vascular compromise and BT severity.

Conclusively, intestinal obstruction by its types is associated with BT precursors. BT is functioning during I.O, has bidirectional routes most pathogens are enteric, specially E.coli with obligate anaerobe occasionally in the ischemic variant. Bacterial overgrowth, virulence and wall structure and function work together. Both the BT and cytokine generating hypothesis are operational during I.O, and the 3 hit model is the appropriate model. The CRP is a non selective diagnostic marker in suspected cases of I.O but once diagnosed is a significant predictor of its subtypes. The CRP is a reliable test of BT during I.O. The CRP is a predictor of vascular compromise and BT severity.

\section{References}

1. Cevikel MH, Ozgun H, Boylu S, Demirkiran AE, Aydin N, Sari C, Erkus M. C-reactive protein may be a marker of bacterial translocation in experimental intestinal obstruction. ANZ J Surg. 2004;74(10):900-4. 2. Deitch EA. Bacterial translocation or lymphatic drainage of toxic products from the gut: what is important in human beings? Surgery. 2002;131(3):241-4.

3. Gatt M, Macfie J. Bacterial translocation in surgical patients. Recent Adv Surg. 2005;28:23-32.

4. Deitch EA. Simple intestinal obstruction causes bacterial translocation in man. Arch Surg. 1989;124(6):699-701.

5. Nieuwenhuijs VB, Verheem A, van Duijvenbode-Beumer H, Visser MR, Verhoef J, Gooszen HG, Akkermans LM. The role of interdigestive small bowel motility in the regulation of gut microflora, bacterial overgrowth, and bacterial translocation in rats. Ann Surg. 1998;228(2):188-93

6. Lane JS, Todd KE, Lewis MP, Gloor B, Ashley SW, Reber HA, McFadden DW, Chandler CF. Interleukin-10 reduces the systemic inflammatory response in a murine model of intestinal ischemia/reperfusion. Surgery. 1997;122(2):288-94.

7. Choudhry MA, Fazal N, Goto M, Gamelli RL, Sayeed MM. Gutassociated lymphoid $\mathrm{T}$ cell suppression enhances bacterial translocation in alcohol and burn injury. Am J Physiol Gastrointest Liver Physiol. 2002;282(6):G937-47.

8. Kanda T, Fujii H, Tani T, Murakami H, Suda T, Sakai Y, Ono T, Hatakeyama $\mathrm{K}$. Intestinal fatty acid-binding protein is a useful diagnostic marker for mesenteric infarction in humans. Gastroenterology. 1996;110(2):339-43.

9. Johnson HL, Chiou CC, Cho CT. Applications of acute phase reactants in infectious diseases. J Microbiol Immunol Infect. 1999;32(2):73-82.

10. Westhuyzen J, Healy H. Review: biology and relevance of C-reactive protein in cardiovascular and renal disease. Ann Clin Lab Sci. 2000;30(2):133-43.

11. Lowry OH, Rosebrough NJ, Farr AL, Randall RJ. Protein measurement with the Folin phenol reagent. J Biol Chem. 1951;193(1):265-75.

12. Paglia DE, Valentine WN. Studies on the quantitative and qualitative characterization of erythrocyte glutathione peroxidase. J Lab Clin Med. 1967;70(1):158-69.

13. Shah KA, Shurey S, Green CJ. Characterization of apoptosis in intestinal ischaemia-reperfusion injury: a light and electron microscopic study. Int J Exp Pathol. 1997;78(5):355-63.

14. Nanis ON. Comparative evaluation of the effects of electrical stimulation and therapeutic ultrasound on wound healing in rabbits [MD Thesis]. Mansoura: Mansoura Faculty of Medicine; 1993. 
15. Akin ML, Uluutku H, Erenoglu C, Ilicak EN, Elbuken, Erdemoglu A, Celenk T. Hyperbaric oxygen ameliorates bacterial translocation in rats with mechanical intestinal obstruction. Dis Colon Rectum. 2002;45(7):967-72.

16. Sagar PM, MacFie J, Sedman P, May J, Mancey-Jones B, Johnstone D. Intestinal obstruction promotes gut translocation of bacteria. Dis Colon Rectum. 1995;38(6):640-4.

17. Wilson J, Winter M, Shasby DM. Oxidants, ATP depletion, and endothelial permeability to macromolecules. Blood. 1990;76(12):2578-82. 18. Welsh MJ, Shasby DM, Husted RM. Oxidants increase paracellular permeability in a cultured epithelial cell line. J Clin Invest. 1985;76(3):1155-68.

19. Swank GM, Deitch EA. Role of the gut in multiple organ failure: bacterial translocation and permeability changes. World J Surg. 1996;20(4):411-7.

20. Schoenberg MH, Poch B, Younes M, Schwarz A, Baczako K, Lundberg C, Haglund U, Beger HG. Involvement of neutrophils in postischaemic damage to the small intestine. Gut. 1991;32(8):905-12.

21. Zingarelli B, Yang Z, Hake PW, Denenberg A, Wong HR. Absence of endogenous interleukin 10 enhances early stress response during post-ischaemic injury in mice intestine. Gut. 2001;48(5):610-22.

22. Souza DG, Vieira AT, Soares AC, Pinho V, Nicoli JR, Vieira LQ, Teixeira MM. The essential role of the intestinal microbiota in facilitating acute inflammatory responses. J Immunol. 2004;173(6):4137-46.

23. O'Boyle CJ, MacFie J, Dave K, Sagar PS, Poon P, Mitchell CJ. Alterations in intestinal barrier function do not predispose to translocation of enteric bacteria in gastroenterologic patients. Nutrition. 1998;14(4):358-62.

24. Akcay MN, Capan MY, Gundogdu C, Polat M, Oren D. Bacterial translocation in experimental intestinal obstruction. J Int Med Res. 1996;24(1):17-26.

25. Antequera R, Bretana A, Cirac A, Brito A, Romera MA, Zapata R. Disruption of the intestinal barrier and bacterial translocation in an experimental model of intestinal obstruction. Acta Cient Venez. 2000;51(1):18-26.

26. Kocdor MA, Kocdor H, Gulay Z, Gokce O. The effects of pentoxifylline on bacterial translocation after intestinal obstruction. Shock. 2002;18(2):148-51.
27. Boedeker EC. Adherent bacteria: breaching the mucosal barrier? Gastroenterology. 1994;106(1):255-7.

28. Wells CL, Maddaus MA, Reynolds CM, Jechorek RP, Simmons RL. Role of anaerobic flora in the translocation of aerobic and facultatively anaerobic intestinal bacteria. Infect Immun. 1987;55(11):2689-94.

29. O’Boyle CJ, MacFie J, Mitchell CJ, Johnstone D, Sagar PM, Sedman PC. Microbiology of bacterial translocation in humans. Gut. 1998;42(1):29-35.

30. Mainous MR, Tso P, Berg RD, Deitch EA. Studies of the route, magnitude, and time course of bacterial translocation in a model of systemic inflammation. Arch Surg. 1991;126(1):33-7.

31. Brooks SG, May J, Sedman P, Tring I, Johnstone D, Mitchell CJ, MacFie J. Translocation of enteric bacteria in humans. Br J Surg. 1993;80(7):901-2. 32. Moore FA, Moore EE, Poggetti R, McAnena OJ, Peterson VM, Abernathy CM, Parsons PE. Gut bacterial translocation via the portal vein: a clinical perspective with major torso trauma. J Trauma. 1991;31(5):629-36

33. MacFie J, O’Boyle C, Mitchell CJ, Buckley PM, Johnstone D, Sudworth P. Gut origin of sepsis: a prospective study investigating associations between bacterial translocation, gastric microflora, and septic morbidity. Gut. 1999;45(2):223-8.

34. Lemaire LC, van Lanschot JB, Stoutenbeek CP, van Deventer SJ, Dankert J, Oosting H, Gouma DJ. Thoracic duct in patients with multiple organ failure: no major route of bacterial translocation. Ann Surg. 1999;229(1):128-36.

35. Adams CA Jr, Xu DZ, Lu Q, Deitch EA. Factors larger than $100 \mathrm{kd}$ in post-hemorrhagic shock mesenteric lymph are toxic for endothelial cells. Surgery. 2001;129(3):351-63.

36. Deitch EA, Xu D, Franko L, Ayala A, Chaudry IH. Evidence favoring the role of the gut as a cytokine-generating organ in rats subjected to hemorrhagic shock. Shock. 1994;1(2):141-5.

37. Willetts IE, Kite P, Barclay GR, Banks RE, Rumley A, Allgar V, Stringer D. Endotoxin, cytokines and lipid peroxides in children with intussusception. Br J Surg. 2001;88(6):878-83.

38. Moore FA. The role of the gastrointestinal tract in postinjury multiple organ failure. Am J Surg. 1999;178(6):449-53.

Conflict of interest: none Financial source: none

\section{Correspondence:}

Saleh Ibrahim El-Awady, MD

Surgery Department

Mansoura Faculty of Medicine

0123913125

elawadysaleh@yahoo.com

Received: November 5, 2008

Review: January 7, 2009

Accepted: February 10, 2009

\section{How to cite this article}

El-Awady SI, El-Nagar M, El-Dakar M, Ragab M, Elnady G. Bacterial translocation in an experimental intestinal obstruction model. C-reactive protein reliability? Acta Cir Bras. [serial on the Internet] 2009 Mar-Apr;24(2). Available from URL: http://www.scielo.br/acb

*Color figure available from www.scielo.br 